\title{
萌出時期におけるラット臼歯裂溝内細菌叢の 電子顕徴鏡的観察
}

\author{
尾 崎 文子佐藤誠* \\ 寺岡加代岡田昭五郎

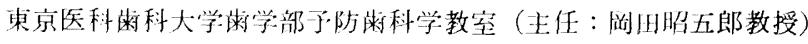 \\ ＼cjkstart徳島大学曾学部予防萪科学教室（主任：中村 亮教授）
}

(1984年12月11日 受付)

\section{Electron Microscopic Study of Bacterial Colonization in Fissures of Rat Molars During Eruption Period}

\author{
Fumiko Ozaki, Makoto Sato*, Kayo Teraoka and Shōgoro Okada \\ Department of Preventive Dentistry and Public Health, Faculty of Dentistry \\ Tokyo Medical and Dental University (Chief : Prof. Shōgoro Okada) \\ * Department of Preventive Dentistry, School of Dentistry, The University of \\ Tokushima (Chief : Prof. Ryo Nakamura)
}

\begin{abstract}
The fissures of the rat molars were examined by the SEM technique with the purpose of demonstrating the change in the bacterial colonization according to the period of tooth eruption. The bacteria began to adhere to the entrance of the fissures as soon as the molars appear in the oral cavity and the colonization extended up to the deeper places of the fissures with eruption.

At the completion of eruption, the bacteria were observed at the lower part of the fissure. Only a slight difference was found in the formation of the bacterial plaque in the fissures when the rats were given different diets.

Extracellular polysaccharide was observed in the fissures of rats provided with diet containing sucrose.
\end{abstract}

\section{I . 緒言}

ラットの曰画は裂溝底部の幅がヒトの裂清とほ ぼ等しく1，ヒトのウ蝕に類似したウ窩が形成さ れるために裂溝ウ蝕のモデルとして広く利用され ている。ラットの裂溝ウ蝕は口腔内常在菌の $1 つ$ であるS. mutans の感染によって発生する疾病と

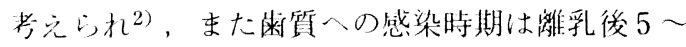
10日（日䕆 26〜31日）と報告されている3)。一方 wistar 系ラットの臼米萌出時期は, $\mathrm{M}_{1}$ で19日齢， $\mathrm{M}_{2}$ で21 日齢であるから前述の感染時期を考兄合 わせるとS. mutans は萌山直後のかなり早い時期 に歯質内に侵入するものと考えさるを得ない。し たがってそれに先立つS. mutans の裂溝内への定 着も，臼雨の歯冠部が完全に露出する以前にすで に始まっているものと思われる。

口腔内微生物のラット曰歯裂溝内部での増殖に 関しては, Kalberer, P. U.ら $(1971)^{4)}$ が，離乳後 
sucrose を含むウ蝕誘発性食慨を与えられたラッ トの裂溝内細菌集落について, 透過型電顕を用い て観察を行い, 裂溝内部の組織の消失に伴って細 菌の量が増加していくことを示しているが，裂溝 内への細菌の侵入や集落形成の時期についての報 告はない。そこでわれわれは, 裂溝内部への細菌 の侵入之定着, 集落形成がどのような時期から始 まり，ウ蝕とどのよらなかかわりを持つかを検討 するために, 萌出前から離乳後 7 日までのラット 臼歯裂溝内の細菌叢の変化を走査型電子顕微鏡を 用いて観察したので報告する。

\section{II. 材料と方法}

\section{1. 動 物}

当教室で継代飼育中の wistar 系ラットを用い, 16日齢より27日齢まで経時的に観察を行った。 21 日齢で離乳し，同腹のラットを 2 群に分け，一方 の群にはウ蝕誘発性食䬲 Diet-20005)（船橋農場 製）を，他方の群には飼育用粉末飼料 CE-2（日 本クレア製）を与えた。飲料水は蒸溜水とし, 飼 料, 水は自由に摂取させた。

\section{2. 標本の作製}

ラットは16日歯より離乳後 7 日まで毎日 5 匹ず つクロロフォルム麻酔下で殺し, 下顎曰歯を摘出 し，たたちにカルノア液で固定した。固定後臼歯 裂溝部を観察するために, 㤠溝部を中心にダイヤ モンドディスクで近遠心的に 2 分割し, 分割面を エメリペーパーで軽く研磨し標本を作製した。標 本は etylalcohol で脱水, $\mathrm{CO}_{2}$ の臨界点乾燥, $\mathrm{Pt}$ のイオン蒸着を行い電顕用試料とした。

\section{3. 標本の観察}

走査型電子顕微鏡（日立450）で裂溝内部の状態 を観察した。

\section{III. 結果}

1. wistar系ラットの臼雨 $\mathrm{M}_{1}$ は17日龄で咬頭 頂の一部が萌出し，20日粭で葫出が完了する。 $\mathrm{M}_{2}$ は20日 齢で咬頭頂の一部が萌出し22２3日柃 で萌出が完了する（図 $1,2,3,4) 。$

2. 萌出前に歯冠部全体を覆っていた ameloー blast は，萌出に伴って咬頭頂より消失していく が，萌出完了時にはまだ裂溝底部に残っている (図 $5,6,7$ )。

3. 細菌の付着は19日齢 $\left(\mathrm{M}_{1}\right)$ で裂溝入口附近 や裂溝上部内壁に球菌, 桿菌がみられる（図8， 9 )。2 0 日莑の $\mathrm{M}_{1}$ では裂溝深部まで細菌が侵入 し,一部に filamentousな菌も観察された（図10, 11)。21日齢の $M_{1}$ では裂溝底部まで細菌の集落 が形成されている(図12，13，14，15，16)。離乳 後（21 27日齢）は, 㤠溝内の菌数は経時的に急 速に増加し，27日㱓では裂溝内は細菌集落で満た されていた。2 種類の飼料 (Diet-2000 と CE-2) の差異による細菌数の増加, 細菌の形態等に差は みられなかったけれども， sucrose 56\%を含む Diet-2000 飼育群の裂溝内には菌体外多糖類と思 われる物質が形成されている像が観察された（図 $17,18,19,20,21,22,23)$ 。

\section{IV. 考察}

ラットは裂溝ウ蝕のモデルとして使用されてい るが，この実験結果から裂溝内への細菌の侵入と 定着は, 歯冠の出敬とともに開始し $\mathrm{M}_{1}$ では離乳 前, $\mathrm{M}_{2}$ では離乳時に裂溝底部にまですすむこと が認められた。ラットの臼雪はほぼ４日で萌出を 完了するが, 完全に萌出した時点では裂溝底部に はまだ ameloblast が残っているものの，崩壊し た ameloblast の部位にまですでに細菌が侵入し ていることが認められた。また細菌の侵入状態や 菌量に関しては，ラットの飼育飼料によるちがい は少なく、いずれも萌出自後には球菌, 桿菌が多 く，その後 filamentous な菌が認められるよらに なった。けれども砂糖の多い慨 (Diet-2000)を与 えた群では菌体間に多糖類様物質の形成がみられ た。これらの知見は Kalberer, P. U. ら (1971 $)^{4)}$ の報告と一致している。

一方, ヒトの裂溝蛍の初発に関しては Löe, H. $5(1973)^{6)}$, Theilarde, E. $5 \quad(1973)^{7)}$, Karring, T. 5 $(1974)^{8)}$ は，人工裂溝を用い，ま た Theilarde, E. ら $(1978)^{9)}$, Thott, E. K.ら $(1974)^{10)}$ は末萌出の第 3 大臼歯裂溝部分を利用し 
て，菌叢の変化を調べたものが報告されている。 これらはいずれも試料片を口腔内に装着してその

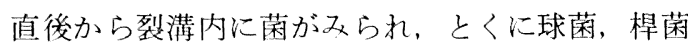
の占める割合が多く, filamentous な菌が少ない と報告されて扣り，このことは平滑面の歯垢との らがいと述べられている。ラットの場合はわれわ れの観察では, 球菌, 桿菌とともに filamentous な菌も裂溝深部に観察された点がヒトの場合と異 なっていた。これはラットの裂溝形態が煩舌的に 広がっていることも影響しているのかもしれな w。

Liisa, S. (1984)11) は臨床的に健全な萌出途上の 第 3 大臼歯の裂溝を走查型電子顕微鏡で観察し， 表層下のエナィル質内， D-E junction，Dentin への細菌の侵入状態を調べ，細菌の歯質内への侵 入が非常に早く起こることを示している。今回の われわれの観察では裂溝内への細菌の侵入や增殖 には，ウ蝕誘発性食慨と通常の飼育食慨による差 はほとんど恐められなかった。しかしラットのウ 蝕誘発実験では，明らかにウ蝕誘発性食飰を与兄 た群でウ蝕が多発することから，裂溝内に定着す る菌の種類のみならず与光る食飭, さらに歯質,

ラットの健康状態等が歯質内への細菌の侵入に影 響することが考兄られ，これらの関連性について はさらに検討する必要があると考光ている。

\section{V. をとめ}

萌出時のラット臼歯㤠溝内一の細菌の侵入定着 状態を臼歯 $\left(\mathrm{M}_{1}\right)$ 萌出前の16日齡より27日齢（離 乳後 7 日）まで走査型電子顕微鏡を用いて観察し た。細菌は歯冠部が口腔内に露出するとすぐにエ ナィル質表面に付着しはじめ, 萌出に伴って裂溝 内に侵入し, 萌出が完了した時点では裂溝底部に まで細菌の集落が認められた。離乳後のラットの 飼料として, 砂糖 $56 \%$ を含むウ蝕誘発性食餌 Diet-2000，㧍上び普通飼育用粉末飼料 CE-2 の 2 種を用いたが 2 群の間に細菌の種類, 菌量の差は みられなかった。Diet-2000を与えた群では菌体 のまわりに多糖類様物澌が形成されているのが観 察された。

\section{謝 辞}

稿を終わるにあたり走査型電子顕微鏡の操作，観察 を懇切にご指導下さいました本学中央電子顕微鏡室宮 本泰博先生に厚くお礼申し上げます。また本実験に関 しご助言いただきました北里研究所 鶴水隆先生に感 謝いたします。

本研究の要旨は第31回口腔衛生学会総会で発表し た。

本研究の一部は文部省科学研究費補助金によった。

\section{文献}

1) Rasebury, T. : The problem of dental caries. Dental Science and Dental Art. Lea and Febign, 269, 1938.

2) 大西正男：鼠う蝕による St. mutans の感染機 㩐とう蝕の子防体系. 口腔衛牛会誌 $25: 105-$ $114,1975$.

3）大西正男，尾崎文子，村上淑子：ラット潾牙年 粭とS. mutans 感染に対するラットの抵抗増 加. 口腔衛生会誌 $23: 116-117,1973$.

4) Kalberer, P. U., Schroeder, H. E., Guggenheim, B. and Muhlemann, H. R. : The microbial colonization in fissures. A morphological and morphometric study in rat molars. Helv. Odont. Acta. 15 : 1-14, 1971.

5) Keyes, P. H. and Jordan, H. V. : Periodontal lesion in the Syrian hamster III. Findings related to an infections and transmissble component. Arch. Oral Biol. 9 : 377-414, 1964.

6) Löe, H., Karring, T. H. and Theilarde, E. : An in vitro method for the study of the microbiology of occlusal fissures. Caries Res. $7: 120$ 129, 1973.

7) Theilarde, E., Larson, R. H. and Karring, T. H.: Microbiological studies of plaque in artificial fissures inplanted in human teeth. Caries Res. 7: 130-138, 1973.

8) Karring, T., Ostergaard, E., Theilade, J. and Löe, H. : Histochemical study of the formation of dental plaque in artificial fissures. Scand. J. Dent. Res. 82 : 471-483, 1974.

9) Theilade, E., Fejerskov, O., Karring, T. and Theilade, J. : A microbiological study of old plaque in occlusal fissures of human teeth. Caries Res. 12 : 313-319, 1978.

10) Thott, E. K., Folde, L. E. A. and Sveen, O. B. : A microbiologic study of human fissure plaque. Scand. J. Dent. Res. 82 : 428-436, 1974. 
11) Liisa, S. : Scanning electron microscopic study of early subsurface bacterial penetration of human molar fissure enamel. Arch. Oral. Biol. 29 : 503-506, 1984. 


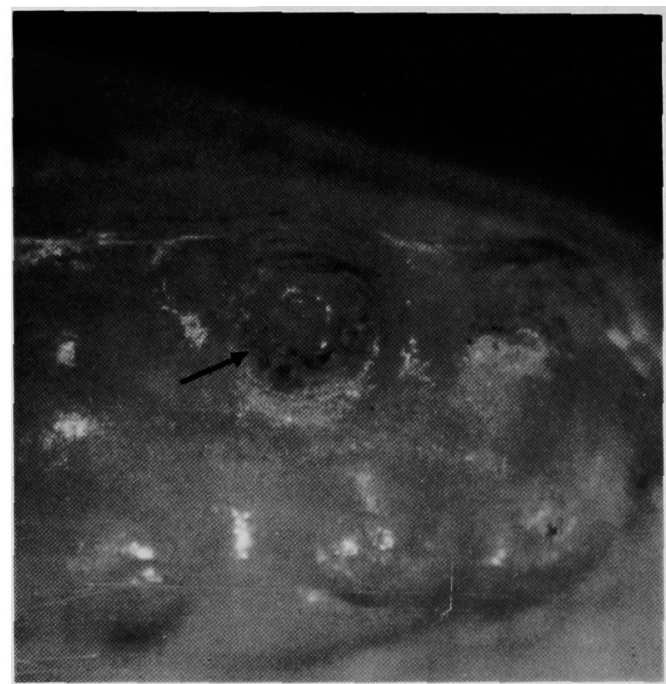

图1 17 日路 $M_{1}$ 咬頭部

咬頭頂が 1 筒所わずかに胡出しはじめている (矢印)

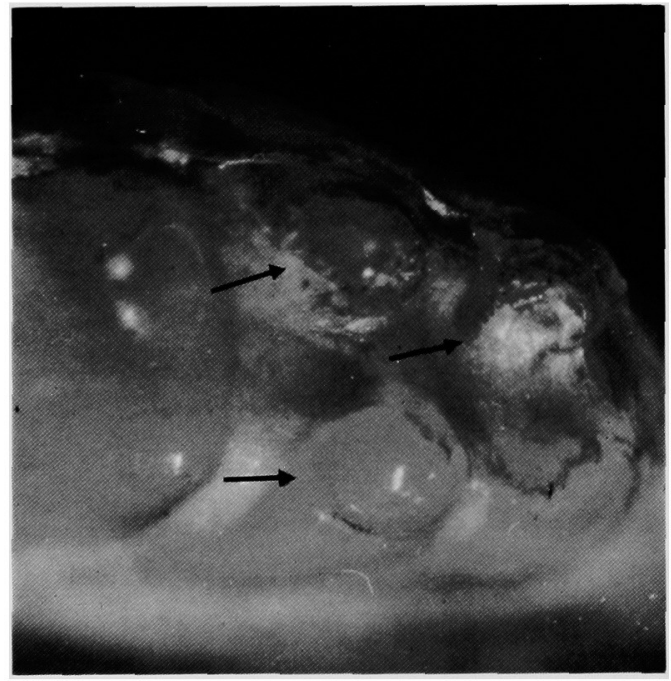

図 218 日粭 $M_{1}$ 咬頭部 咬頭頂が 3 筒所萌出している（矢印）

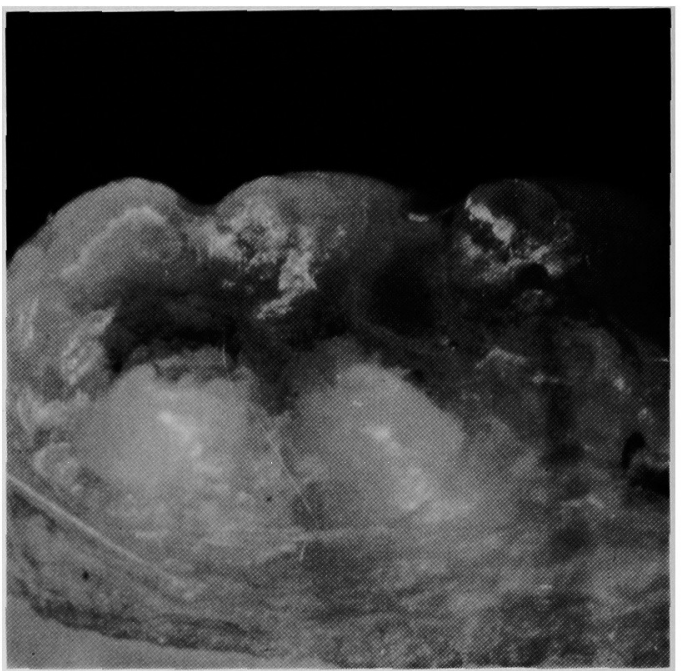

図3 19日路 $M_{1}$ 咬頭部 米冠部がほぼ全体に萌出している

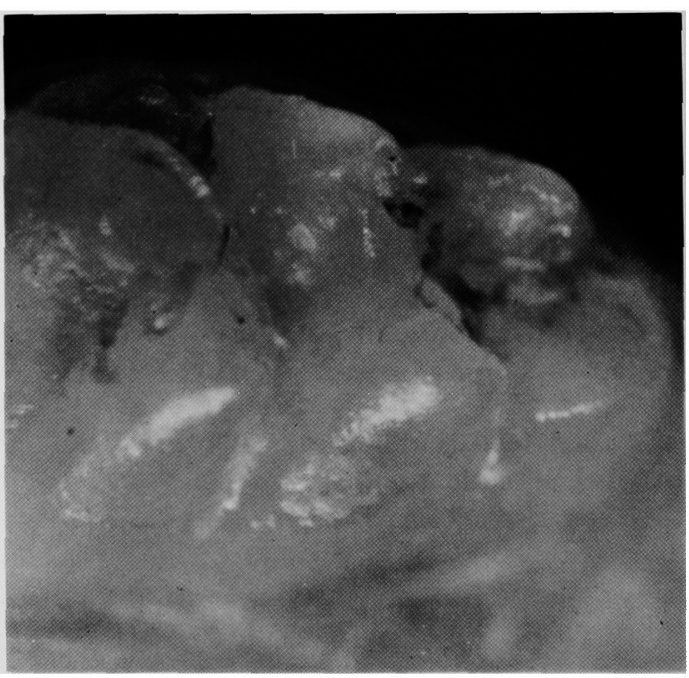

図 420 日柃 $M_{1}$

萌出が完了し歯冠部が完全に露出している 


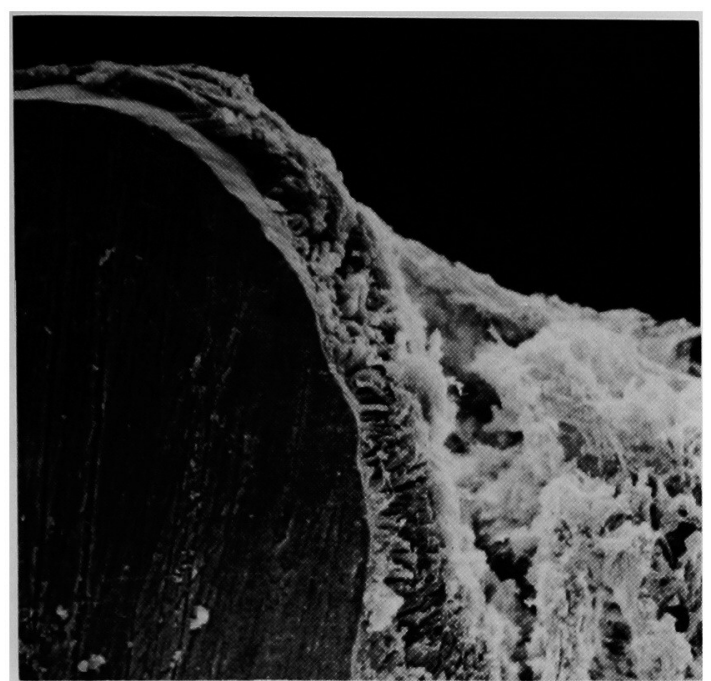

図 516 日齢 $M_{1}$ 咬頭部

萌出前の状態で全体に ameloblastに覆われている。 $\times 200$

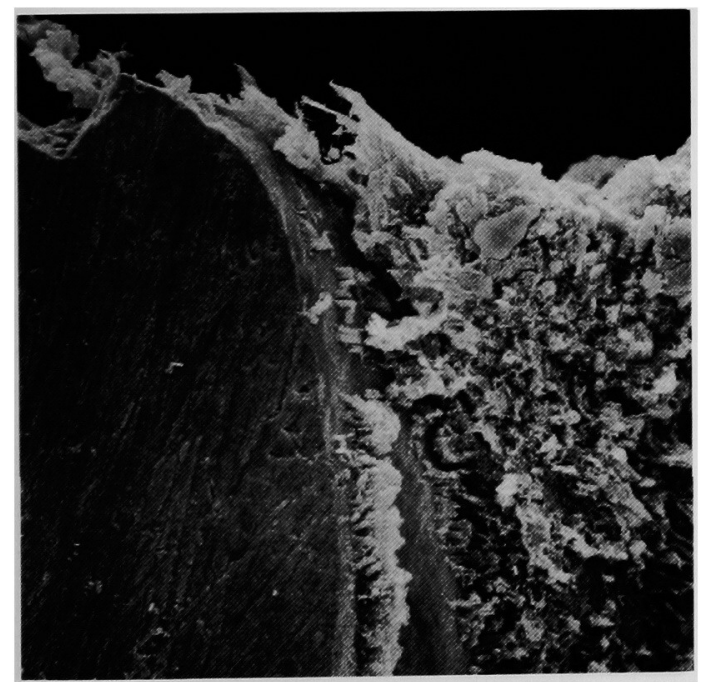

図6 17日齢 $\mathrm{M}_{1}$ 咬頭部

咬頭頂の一部が朝出し ameloblast が崩壊し始め ている。 $\times 200$

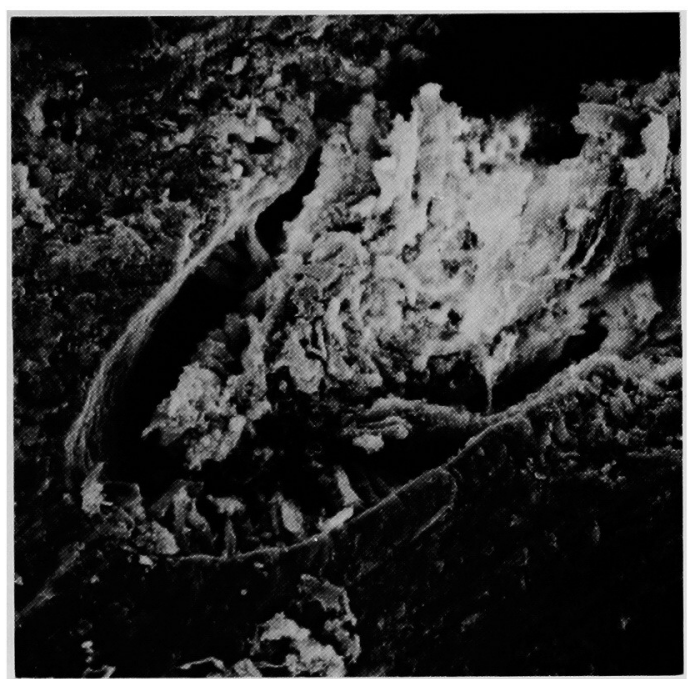

図 721 日踹 $M_{1}$ 裂渾内部

米冠部が完全に萌出した時点でも裂溝底部に

は ameloblast が残っている。 $\times 200$

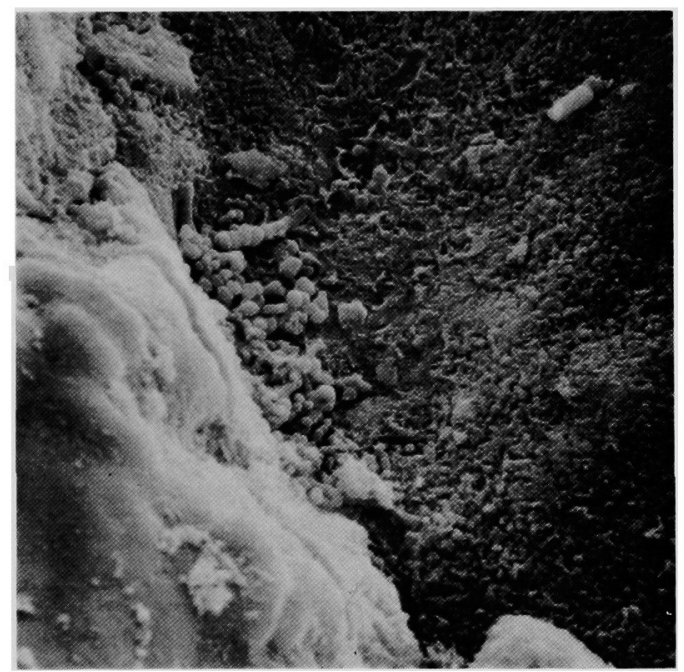

図 819 日龄 $\mathrm{M}_{1}$ 裂溝入口

球菌の集落がみられる。 $\times 2,000$ 


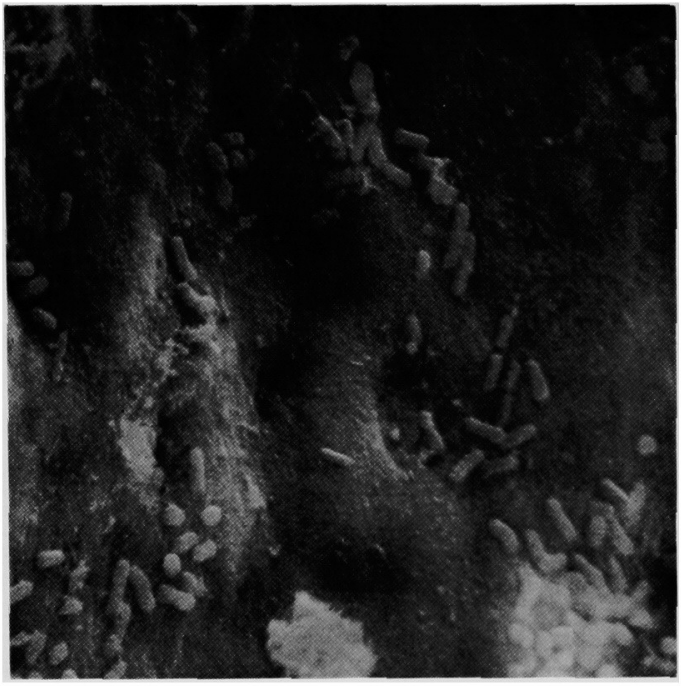

図 9 19日踰 $\mathrm{M}_{1}$ 裂瑇上部内壁

球菌, 桿菌が付着している。 $\times 4,000$

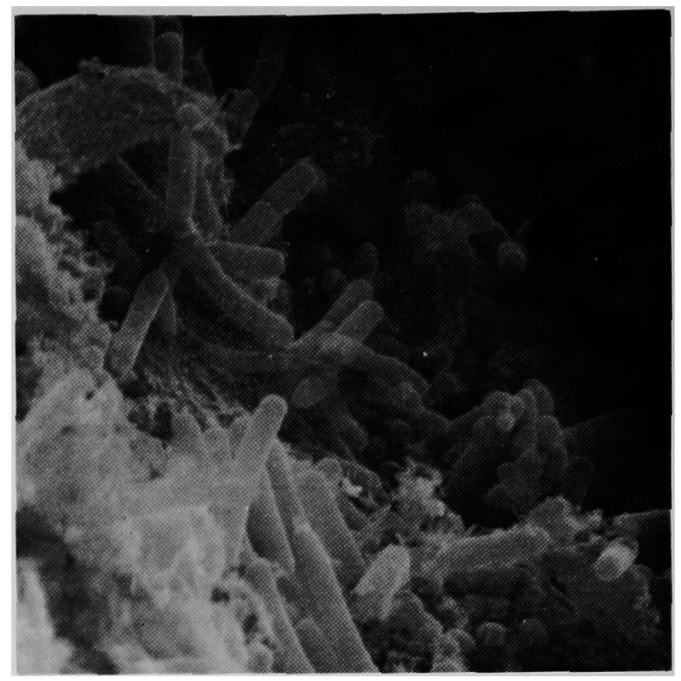

図1120日路 $M_{1}$ 裂满深部

一部に filamentousな菌も観察された。 $\times 8,000$

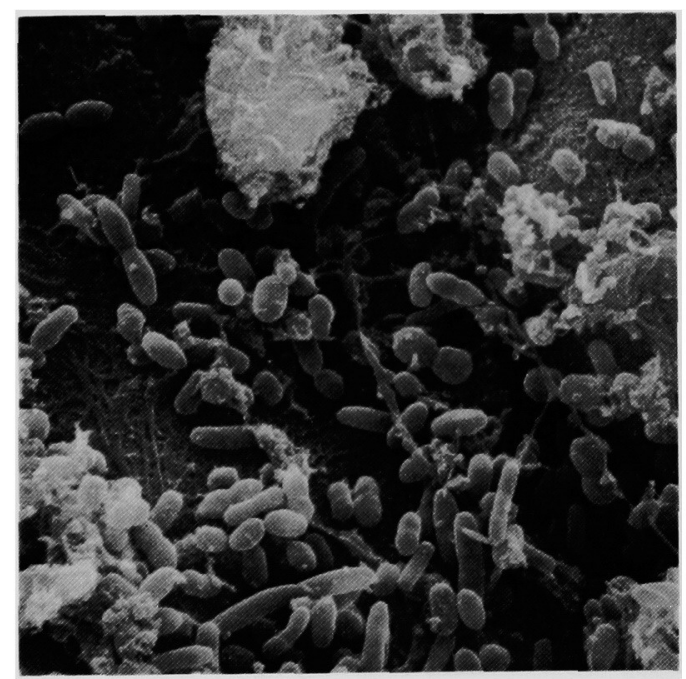

図10 20日齢 $M_{1}$ 裂满深部

裂溝深部に形成された細菌の集落。 $\times 8,000$

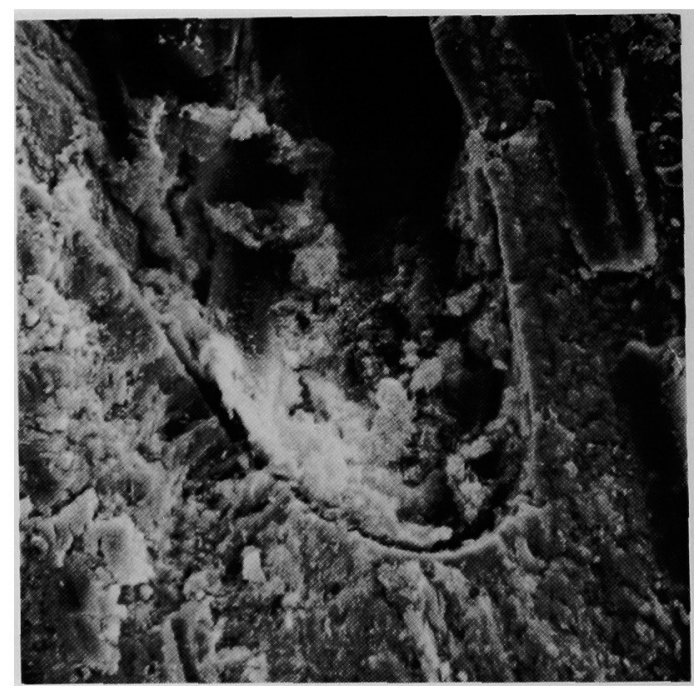

咸12 21 日粉 $M_{1}$ 裂溝底部

崩壤した組織の間に細菌が観察される。 $\times 300$ 


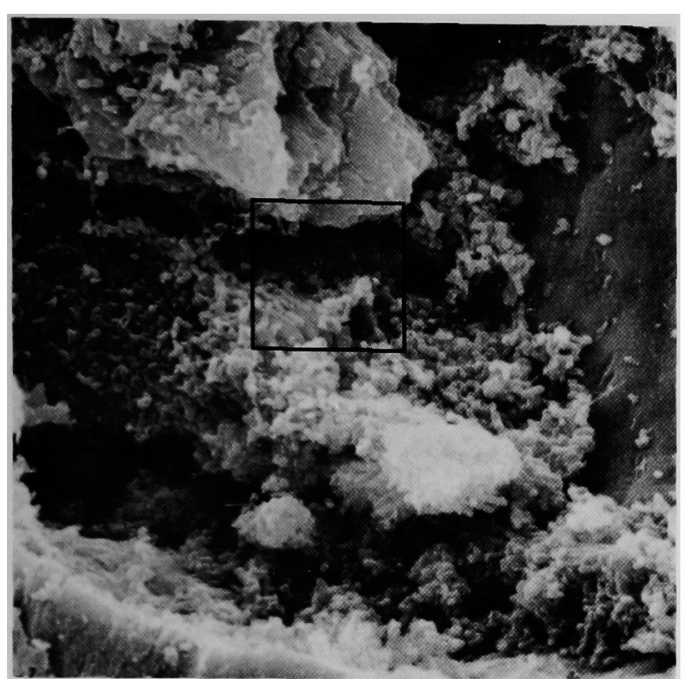

図13 図12の一部拡大図。 $\times 2,000$

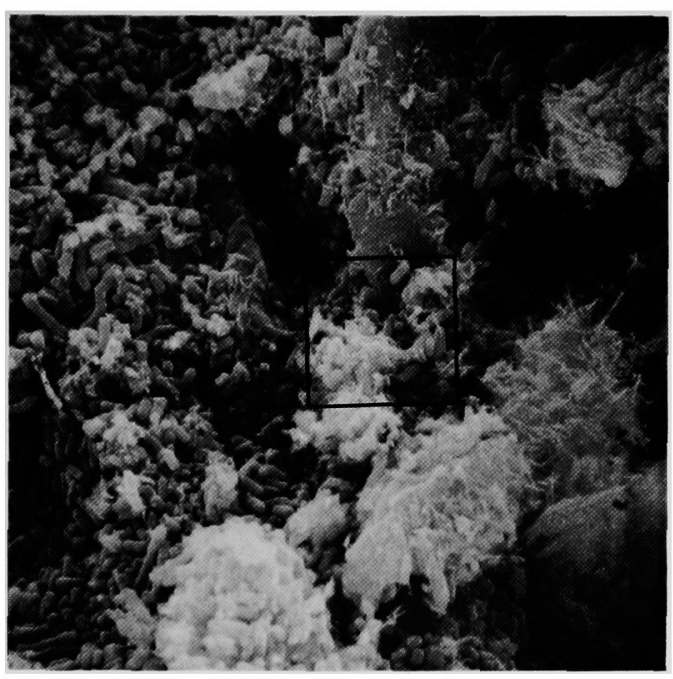

図15図12の一部拡大図。 $\times 2,000$

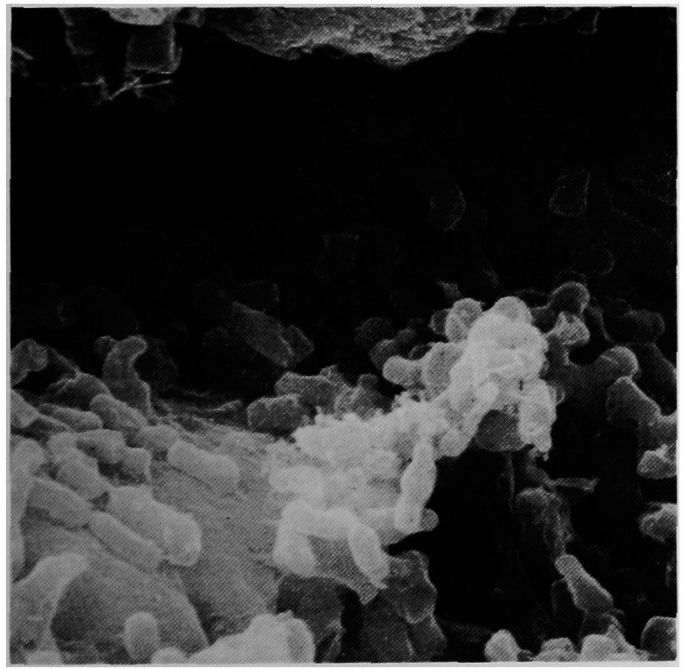

図14図13の一部搪大図。 $\times 8,000$

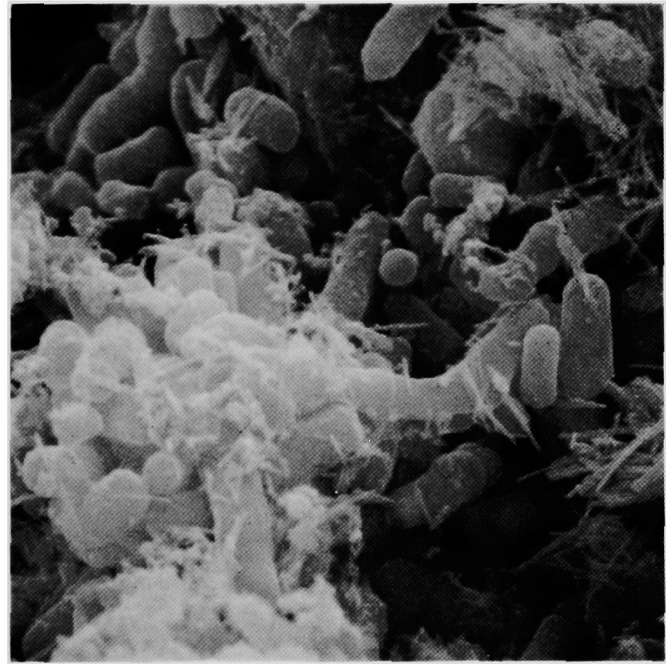

図16図15の一部拡大図。 $\times 8,000$ 


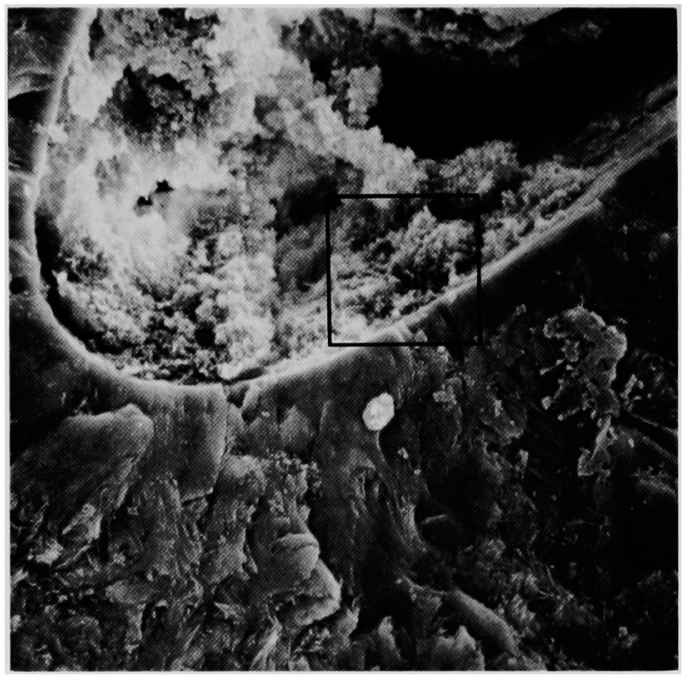

図17 24日䐧 $\left(\mathrm{CE}-2\right.$ 飼育) $\mathrm{M}_{1}$ 裂溝底部 裂溝内の細菌集落。 $\times 800$

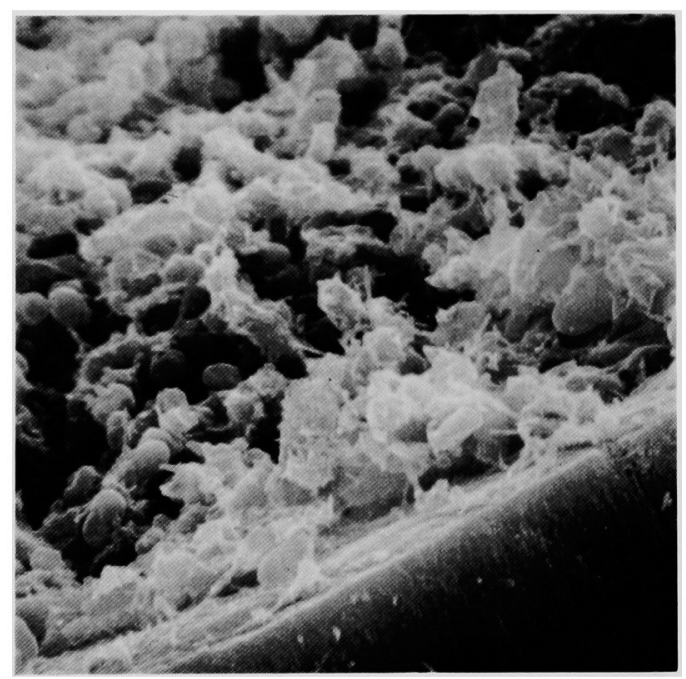

㘠18図17の一部搪大図。 $\times 8,000$

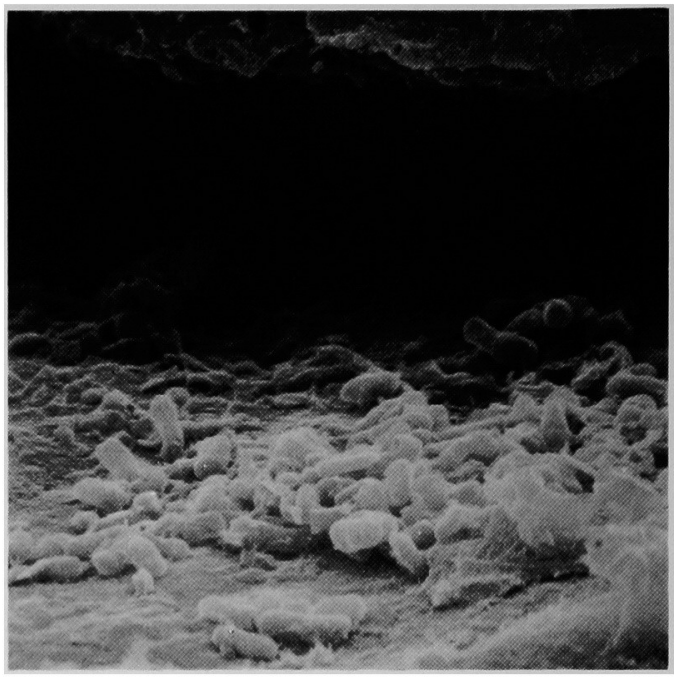

図1924日撂 (Diet-2000 飼育) $M_{1}$ 裂溝底部 裂㲘底部の細菌集落。 $\times 5,000$

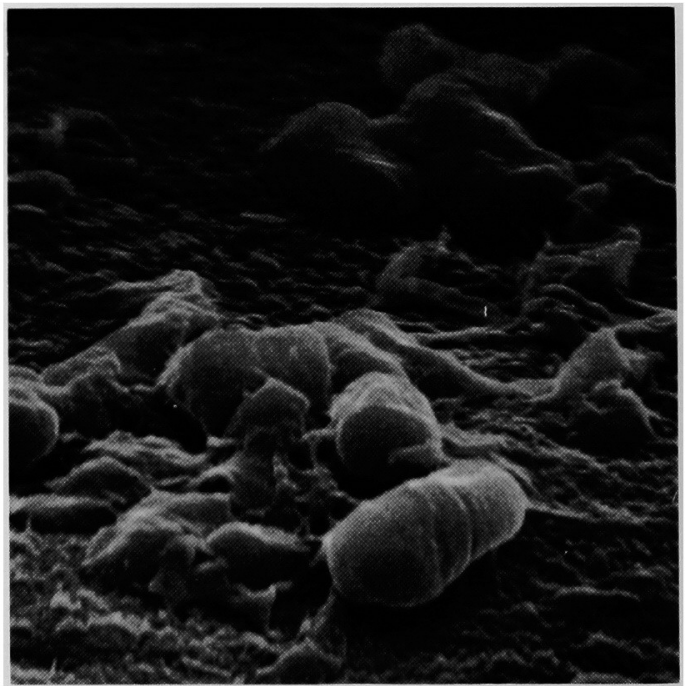

汹20図19の一部拡大図

菌体の周りに多糖類様物質の形成が 久られる。 $\times 20,000$ 


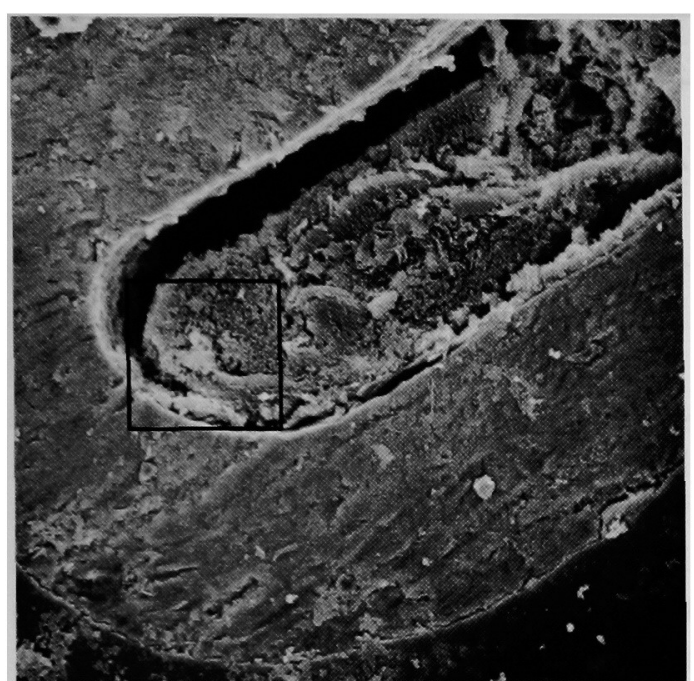

図21 27日齢 (Diet-2000 飼育) $M_{1}$ 裂溝内部 裂溝内は細菌塊で満たされている。

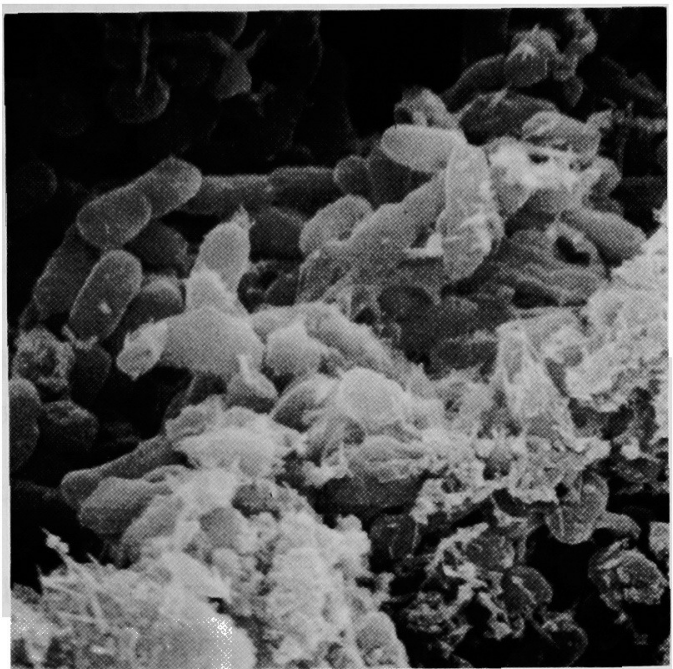

㘠23図22の一部搪大㘠。 $\times 8,000$

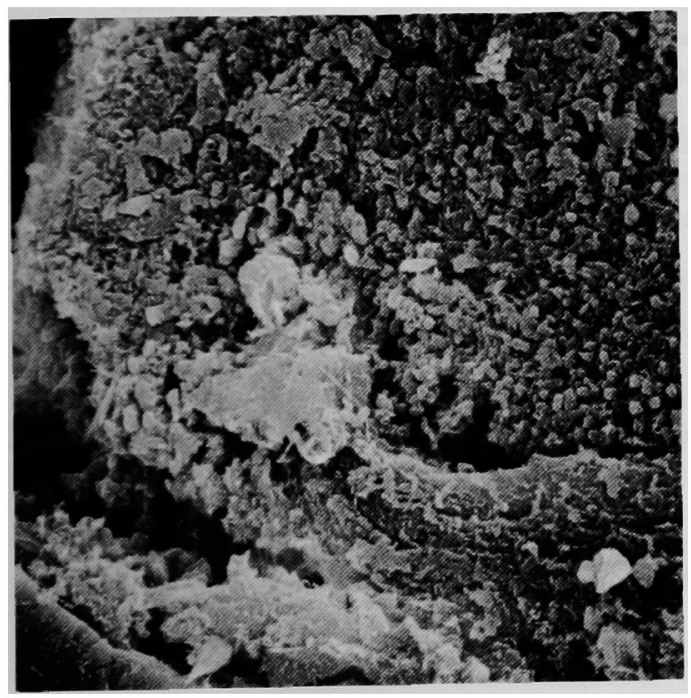

図22図21の一部拡大図。 $\times 2,000$ 